\title{
Erasmus in Italy
}

TN his recent sketch of the life of Erasmus Mr. Fronde has 1 devoted so much space to the relations of his hero with the Reformation movement as to neglect almost entirely' other not less important episodes in his career. It is proposed here to show, partly from the works of Erasmus and partly from the biography by his friend and contemporary Bestus Rhenenus, that the information which we possess of his three years in Italy (1506-1509) is as fall and interesting as is furnished by any other period of his life.

At the time of the Renaissance no northern scholar considered his education as 'finished' until he had spent some months at least in Italy. Especially was this the case in those first golden years of the sirteenth century, when Greek was studied with all the fervour of a new discovery, and when the universities of Bologns and Padus provided adrantages for the student at that time unrivalled. Erasmus, as he tells us himself, had cherished the plan of his Italian tour for more than twenty years, and had thrice been dissppointed for lack of means when he seemed on the eve of success. At length the long-looked-for opportunity came when he was in London in the spring of 1506. The king's physician, Dr. G. Battists Buerio, of Genon, wished to send his sons to study in Italy under the guidance of some literary man; and Erasmus willingly undertook the charge. What his remuneration was we are not told-perhaps not more than his expenses, for he tells us that he was not to be their gusrdian, but simply to take a general oversight of their studies. The lads were accompanied by a rojal

1 Kr. Frondo's conjecture (pp. 78, 84) that there wero two fisits to IIaly-the firt in 1502 or 1503, and the sacond in or after $1507-m a 5$ be eacily diproved. Furthar evidenoe aginst it hes been reoently supplied by a Fremah serant, M. Pierro de Nolbes, who hes printed at Peris (Blinaterieck, 1888), together vith an sdmirable aketch of this pert of Eramos's life, four hitherto unpoblished letter of this period from Eracmas to Aldos, of which the firt, from Bolognen is endorsed by Aldus himsele with the date of 28 Oet 1007. With eight othors of later date thes were found at Rome in the Vatican and Barberini libreries.

2 Mr. Froude follows the error of Mrr. Seebohm and othera in depriving the doztor cf his sarneme - the only ground for this being thet Erasmas, familiarly to his rwo triends, epeaks of him as 'Beptista.' 
courier and by an attendant, named Clyston, who was personally responsible for them; and Erasmus could not contain his disgust alike at the quarrels and the boon companionship of this person with the courier.

The party set out about the end of May, and even at that season they had such bad weather that they were four days in the Channel. Just after their arrival in Paris, Erasmus writes to his friend Linacre, the scholar-physician, that he longs for bis skill to fre him from a torturing headacho-the effect of sessickness.

The glands of my neck are swollen, my temples throb, both my ears are still singing; such a price my Iralian bargain has already cost me. But he had his compensations.

France seems to smile on me all the more sweetly for the freedom, the old associations, and a kind of indalgen's affection shown towards me.

Yet most of his conversation with her sons, as with Englishmen, must have been in Latin, for he never mastered French; he eren calls it somewhere 'that barbarons and irregular language, which is not written as it is pronoonced, with its pecoliar hissings that sound scarcely human.' From the literary point of view his loss was not great, for French literature could then hardly he said to erist. Comines, indeed, was finishing his memoirs at the château of Argenton, but Rabelais was still immured in the convent of Fontensy, and Marot was bird's-nesting in his native Guienne. The acquaintance of Erasmus with that Herculean student, Budé, his rival in after days, seems to have begun ten years later; it was no easy matter to know a man who grambled at getting only sir hourg' work on his wedding-day. Horrever, if Erasmus's friends were so numerous, and were urging him, as be tells us, to take the degree of D.D., it is strange that he did not do so at the university of Paris, the home of his early studies. Perhsps the expense was too great; perhaps, with his new duties, the requirements were too arduous. At any rate he confined himself during his stay at Paris, which must have lasted some weeks, to his Greek studies and to the superintendence of his young charges. In a letter to Colet, dated 12 Jane, he praises their modesty, obedience, and derotion to their work, and prophesies that their future will bring lustre to their native country. He also expresses much regret at his separation from his English friends; 'the whole world,' he says, 'has not gained me so many learned, obliging, virtuous, and sincere friends as the single city of London.' 3 Before leaving Paris he made arrangements with Badius, the printer, to bring out, at an early date,

- Thir specir reforence to London, together with the shortness of bis time in Engined in 1SC6, makes a visit to Cambridgo in the same fer manths rerg improbable. His flect lectures there were in 1510. 
some prose translations of Lucian, and two plays of Enripides in Latin verse. A copy of the latter work was sent to him in Italy abnut six weeks later.

At length, before the end of July, he set out for Turin. It was a long ride of some four hundred miles; but, except a fer nights at Orleans and Lyons, there was no further delay; and early in August the party crossed the Alps. A fer months later Erasmus published, with his Lucian translations, the short poem on old age, which he composed in the course of the journey. Its title, ' $\mathrm{An}$ Equestrian, or rather Alpine Song,' hardly prepares us for its quasi-religious character. The wandering poet, he tells us, is warned by his increasing grey hairs to forsake profane literature for sacred-a warning that was to be strangely neglected in the three following years.

We do not know how long he stayed at Turin; but it was here, and not at Bologna, that he took the degree of D.D. on 4 Sept., moved, perhaps, by the courtesy of the people, with which he was 'marrellously delighted.' We can understand that a university, which had but just completed its centenary and was orershadowed in importance by its more southern Italian rivals, was prond to reckon among its doctors the rising Transalpine scholar. Nineteen years ago the event was commemorated, on its three hundred and seventieth anniversary, by the placing of an inscription under the entrance gate of the university. But Erasmus and his young charges were bound for Bologna, and they could not afford to linger at a less famous school. And so snother ride of 200 miles through the fertile conntry at the base of the Apennines brought them by Pavia and Piacenza to Bologna about the end of September. On their way they certainly visited the grand church of the Carthusians near Pavia, which was not yet completed; and as Erasmus gazed at the splendid pile of white marble, he asked himself why so much money should be spent on a boilding intended only for a ferw solitary monks. He says that they were infested with guests, so that it was only an expense to them, but he does not add whether he himself, the arch-foe of monks, had accepted their hospitality.

It was a most unfavourable moment for the arrival in Italy of one who sought only a studious repose. The army of Lonis XII was still in the Milanese; and Pope Julius II was already on his way to depose Bentivoglio, the despot of Bologns, and restore the city to the Holy See. He fulminated a bull against him from Cesens on 10 Oct., calling on all gond Christians to plunder bis goods and reduce his partisans to slavery. Bentivoglio Fas between two fires; for the French, after promising him their support, went over to the enemy and threatened the city with pillage; and his only resource was to escape to their camp : while the citizens, with the pope's leave, dislodged the French army by closing the slnices 
of their canal and flooding the neighbourhood. It is not surprising that Erasmus, a few days after his arrival, decided that Bologna was bardly a safe place of residence, and retreated across the Apennines to Florence.

Later visitors might well envy his good fortane in entering the great city at such a time. The Medici ware in exile, and most of the literary circle of Lorenzo were dead; but the memory of Saronarols-of his high aims and his terrible fall-was still fresh; and the second secretary of the republic, though be was then absent on a mission to the pope, was Machiarelli. MGichael Angelo and Lionardo were putting the finishing touches to their rival cartoons; and Raphael was perfecting his monderful powers for his later work at Bome. But there is no sign that Erasmus knew, or could appreciate, his opportunities. His stay at Florence was briefperhaps not more than a month; and he basied himself chiefly with his translations of Lucian, as he tells as in the prefatory letter of dedication. One graphic reminiscence he has left us in a letter written twenty years later. He was studying with his pupils in a retired villa close to the walls, when, in the midst of a violent thunderstorm, there was a terrific explosion. The lightning bad strack a tower on the ramparts, which was stored with gunpowder; and the force of the explosion demolished the tower, blowing part of it a distance of two hundred yards : many houses were destroyed, and several lives lost.

The noise was so sudden and so tremendons that all the neighbours thought the sky had burst and the end of the world had come. . . . I was warned to keep within doors, for the town was in arms. In Florence, it seems, when a fire breaks out, they rush to guard the gates and the walls; and it is then hardly prudent to meet any of the people: their wenpons render them fierce, especially when there is any danger.

At the beginning of November he writes: "News has come that Bentivoglio, who fled with his sons, has been slain by the French ; and we shall profit by the peace to retrace our steps to Bologna, as the pope and cardinals will spend the winter there.' Accordingly, Erasmus returned in time to be present on the 11th at their triumphal entry into the town. ${ }^{5}$ The streets were gaily decorated with flags and with arches of greenery, through which the pope marched in arms under a silken canopy, surrounded by bis cardinals, while maidens scattered flowers in his path. We can fancy Erasmus with his keen eyes watching the procession from one of the low arcades of the quaint old town. Whether or not he was the author of the satire 'Julius Exclusus,' where it is vividly

- This news afterwards proved false.

- Soreral of his biographers are in error in supposing from lis orn trords that bo also witnessed the entry into lone on 28 Jarch, 1507. His exprussion is a carcless ano; but it need not bear that meaning, and such a risit is bighly improbable. 
described, we know what his feelings were on witnessing the scene. ' I could not but contrast with a quiet aigh sach triumphs as these with the majesty of the apostles, who trusted to their. hesvenly teaching to convert the world.' At this moment his fature looked dark indeed. There was much talk among the victors of an alliance with the emperor, and of carrying the war into the territory of Venice. The next week he writes almost in despair of perfecting his Greek-the one object of his visit: 'Here there is a strange frost upon study, while war is at boiling-point. I shall do my utmost to flit beck all the sooner.'

It is not certain whether he had an interviow with the warlike pontiff during the latter's three months' stay at Bologns; bat an incident, which Erasmus was fond of relating in after years, makes it not improbable. The attack, due in the first instance to his ignorance of Italian, which wes twice made upon him in the streets of Bologns, becanse his white scapulary was mistaken for the band worn by the plague-physicians, made it necessary for him to apply to the pope for leave to discontinue his religious habit; and the dispensation was readily granted. The reconciliation of Julius with Wichael Angelo- $\$ 0$ graphically described by Vasari-certainly took place at this time. The famons sculptor was in Bologna doring the whole year of Eramus's stay, engaged apon the great bronse statue of the pope, which stood for three years in the square before the cathedral, and was then melted down into a cannon by the French.

In one of his later letters Erasmus speaks of this. year at Bologna, perhsps with some exaggeration, as one of the most unpleassnt of his life. It is troe that the summer of 1507 was exceptionally hot, and that the climate of the city, never too healthy, drove him for a time into the country; it is probsble, too, that his relations with his pupils, and especially with their attendant, proved irksome to him, and were abraptly closed by a quarrel with the father before the end of the year. But, in spite of his first forebodings, it was a year of peace, and also of intense application and great progress in his claseical studies. The university was not, perhaps, then so brilliant a centre of learning as it had been in the previous generation; but the memory of two celebrated professors, Beroaldo and Urceo-both friends and correspondents of Politianwas still fresh; and the learned society must hare been much to the taste of Erasmus. Among the professors were Berosaldo tho joungar, sfterwards librarian to Leo $X$, and Battista Pio, whose eccentric affectation of archaism made him a great mark for satire.?

- Mr. Froude strangely ploces in Bramers's mouth s atatoment that this incident occurred at Paris; but be hes cortainily misundartood the passage. See the letter to Grannius

: On larvinz s lectare by this seholar, Erasmuen being pressed for his opinion of 
With another professor, however, Paolo Bombasio, Erasmus contracted a lifelong friendship. Bombasio had been appointed, only a few months before, to the chair of Greek. He sympathised with Bentivoglio; and, being a man of spirit who never cared to conceal his opinions, he seems to have been persecuted by the victorious party. Erasmus speaks of him as 'a golden-hearted man, the truest friend that ever lived '-and with good reason, for he opened his house to the wandering scholar, and gare him all the time that he conld spare. Erasmus was asked to give public lectures himself, bat he refused, probably from the fear that his northern pronuncistion of Latin would expose him to ridicule. During these months he seems to have been partly occupied on a treatise upon monasticism and on the letters called 'Antibarbari,' which were afterwards lost through the carelessness of his English friend Pace; bat he ras also amassing a vast store of knowledge for a new edition of his 'Adagia.'

His relations with Aldus, however, began on the subject of a much smaller work. The Latin verse translations of Euripidesthe 'Hecubs' and 'Iphigenia in Aulis'- which were printed for him at Paris soon after his departure, had caused Erasmus much dissatisfaction; the pages swarmed with errors, for which the printer was mainly responsible; and though the latter was anrions to bring out another edition, revised and corrected, the anthor feared, as he seys, that he would only correct one fanlt by another, and looked out for more capable assistance. This was the occasion of an interesting letter to Aldus, first published by M. de Nolhac, which Erasmus despatched from Bologns on 28 Oct. 1507. One cannot but admire the tact with which he began a correspondence so important to himself; and I quote bis opening compliments only becsuse they are as true in fact as they were doubtless sincere.

The wish that I have often formed for you, most learned Manutius, is, that as you have shed aboudant light apon Greek and Latin literature by your genius and uncommon lesrning no less than by your art and the splendid types which you nse, so, too, you might derive from them an equal profit to yourself. No one can doubt that the name of Aldus Manutius will be in the monthe of all, to the latest posterity, who shall be initiated into the mysteries of letters; and you pill meet not merely with fame, but with warm affection for the zeal which you have displayed in restoring and extending the study of good writers. As with Hercoles of ald, the care which you give to your glorious labours will one day gain you immortality, but in the meantime it is more profitable to others than to yourself.

After expressing his delight, together with the rest of the learned world, at the promised edition of Plato, and his surprise that the 
New Testament had not yet isaced from so famous a press, Erasmus comes to the subject of his letter.

I sand you two tragedies which I have translated-boldly enough, bat whether happily or not I leave you to judge. Linscre, Grocyn, Latimer, and Tonstail-your friends as well as mine-have given their high approval-men whom you know to be too learned to fail in their judgment, and too sincere to wish to flattar a friend, unless they are blinded by their affection for me; and the Italians who have the work do not condemn it. . . . I should regard my effusions as sure of immortality if they should issue from your press, and, above all, in that splendid minate type ${ }^{\circ}$ of yours. Thas the volume wonld be very small snd could be completed at a trifling expense.

He goes on to explain that he asks no personal profit for the edition, except 8 fer presentation copies for his friends.

But if you positively require me to tsise 100 or 200 copies, though the god of gain is not generally very propitious to me, and it would be an awkward addition to my baggage, I will make no difficalty about it, if you will lindly fix a fair price.

Aldus accepted tho offer with enthusiasm; and in the nest letter Erasmus courteously declines a pressing invitation to visit Venice on the score of his health, which had suffered from the olimate of Bologne. He receives the printer's criticisms in the most friendly spirit. 'If you meet with a manifest error, do a friend's kind office by correcting it; and any doubtful point, on which my opinion seems to differ from yours, either leave, or make what change you please : what would I not trust to such a friend as Aldas?' After discussing some questions of text and metre, he begs for the utmost expedition in the printing, becsuse he is proposing to set out for Rome after Christraas, and wants twenty or thirty copies on the best paper as a New Year's gift to his friends at Bologna, 'for I am acquainted,' he adds, ' with all here who make a study or profession of polite lesrning.' His wishes seem to have been gratified ; for the small volume, which is now extremely rare, bears the date of December 1507. It contains a long letter of dedication to Arch. bishop Warham, with an ode to the same prelate and another in honour of England and her royal family. Aldus himself prefixed a short advertisement ' to the studious reader,' in which he spesks of Erasmus as his excellent friend; it is a commendatory introduction to the learned world, congratulating Italy that northern students are now plentiful, and that eren Iceland is sending for professors.

It is difficult to rate too highly the value of this small pablication in spreading the fame of Erasmus. The press of Aldus bad now been established nearly twenty years; and between the years 1494 and 1505 its activity had been so prodigions as to astonish

"He refers to the type s bish pre call 'Itelic, from its invention by Mldus in 1501, who is said to hare copied it from the handwriting of Petrarch. 
Europe. Its publications were awrited in Italy as eagerly as the Waverley novels in England some seventy jears ago; and the improvements made by Aldus in his art-especially the issue of cheap octaros and quartos instead of the ponderous folio-made good literature popular in a new stratum of society. His main object was to print the Greek classics, but he did not confine him. self to this; for before his death in 1515 he had published some of the fathers and the best Latin and Italian writers. Erasmus himself, in his remarks on the Aldine motto, 'Festina lente,' predicts that, if the life of Aldus were spared, he would cover the whole field of literature-Greek, Latin, Hebrew, and Syriac. His derice of the dolphin and anchor was intended as a symbol to express this motto-the dolphin denoting speed, the anchor firmness and constancy. It occurs on some of the coins of the Roman empire, and this suggests to Erasmus the reflexion that, as a literary token, its influence was more useful and its circulation wider, than when it was a medium of mercantile exchange. He tells as that manuscripts used to come in from all parts of Europe, even Hungary and Poland; and the printer's advice was sought by learned men in all parts of the world. The expenses of his establishment were 200 ducats a month; though he was aided by the munificence of the princely families of Carpi and Mrantua, the strain was too great upon his own fortune, and he died poor. He was not free from the troubles of a modern employer, for he was four times interrupted by strikes among his workpeople. His chief difficalty, however, was the unsettled state of Italy consequent on the wars with France. This cause, together with his frequent absence from home, will explain why, for two whole years before this little publication, the Aldine press had been idle. We can fancy the enthusiram which would hail its return to work; nor can we wonder that Erasmus, giving up his journey to Rome, decided, at Bombasio's suggestion, to repair to Venice and offer his 'Adagia' to Aldus.

Early in January 1508 Erasmus paused before a sombre-looking house, still standing on one of the smaller cansls near the Rialto, where he would gee the following inscription to callers over the door :-

Whoever you ara, Aldus esrnestly begs you to state your business in the fewest possible words and be gone-anless, like Hercules to wesry Atlas, you would lend a helping hand. There will always be work enough for you, and all who come this way.

When he had summoned a servant and asked to see the master of the house, he was told that he was engaged. On bis sending in his name, however, Aldus gave him the most cordial welcome, would not hear of his going to an inn, and prepared a room for bim in the house. ${ }^{9}$

- The enecdote is told by Rhenanus. 
At this moment Penice was at the height of her power, though the league of Cambray, a fer months later, was the beginning of her decline. While Erasmus was busy upon his 'Adagia,' news was brought of a great victory of the Venetian general Alviano over the troops of the emperor at Cadore, which compelled the latter to sue for peace. The commerce of the republic was never more flourishing. Her silks, her glass, her leather were conveyed to all parts of Europe, and the discoveries of Columbas and Vasco da Gams, though they had aronsed her jealonsy, had not as yet injured her trade. It was the era of the erection of the splendid court of the doge's palace, while Titian and Giorgione were rising to fame. In litarature Venice had not hitherto taken a high place; but the labours of Aldus and his band of scholnrs had now given her an unwonted pre-eminence. Well might Comines write that she was the most trinmphant city in the world, governed with the greatest wisdom, and serving God with the most solemnity.

It is unfortunate that we have no letters of Erasmus to reeord his impressions of so memorable a time. During his nine months' residence he must have semed almost lost to his northern friends. The fact is sufficiently explained by his intense labours upon his 'Adagia.' He had brought to Venice a rast mass of $\mathrm{Ber}$ material, noted upon the margins of his books; but the printing-house supplied him with many unpublished works that he had never seen. He gratefully acknowledges the zealous help ungradgingly given by famous scholars like John Lascaris and Musurus, the chief coadjutors of Aldus.

I say from expenence that there is not the same friendliness among men of learning with us that there is in Italy. Aldus laid before me all his treasures . . . so, too, did some with whom I had no sogusintance by sight or even by name. I was rash enough to propose that we should begin together-I to write and Aldus to print. In about nine months the Forts wes completed, and daring that time I contracted my fresh oomplaint of the stone. You may well believe how much less useful the bonk would have been but for the manuscripts supplied by men of learning.

The speed with which the work was executed is astonishing; Erasmus says that they used to print six folio pages a day. The first proof was corrected by Serafino, a hired reader; this was revised by the anthor, who made any necessary additions; but the last proof was always read by the head of the house.

When I asked Aldus why he took the trouble, his answer wrs, "I am getting instruction myself.' He was astonished that I could compose so fast in the midst of the distracting noise mede by the compositors.

It is now time to say something of the inner arrangements of this busy household. In 1505 Aldus had married the daughtor of Andrea d'Asols, who had acquired a press at Venice by purchase 
as early as 1479 . No partnership had at first existed botween Andres and his son-in-law, though the former had sometimes given help when required; bat in 1508 there was a more formal union, and the two families seem to have lived under one roof. This was naturally the cause of some discomfort; for no fewer than thirtythree perkons, inclading servants and workmen on the premises, composed the household. The females and children lived almost entirely apart, though Erasmus used to give some of his spare moments to playing with little Manazio, the eldest son of Aldus. There was, indeed, much playful gaiety smong the elders when they unbent after the heavy labours of the day. Erasmus recalls that Aldus once held an imaginary dialogue between them in their old age, asking after his health with a trembling, toothless lisp, and replying to his own query in a jet shriller key. He adds sadly that Aldns was taken from his friends long before the toothless age.

There was one point, however, in the household arrangements which was a cruel torment to Erasmus. The mesls were irregular, and, when they arrived, they were frugal to the verge of parsimony. In one of his latest Colloquies, the 'Opulentia Sordids,' we have a most amusing, if somewhat malicious, picture-of course under feigned names - of the table of Andrea, who acted as master of the honsehold. Granting that the recital is in the main a caricature, we cannot doubt that some of the details are real, for it is fall of touches of Venetian manners. There were only two meals in the day, dinner at one, and aupper-whenever Andrea came homesometimes as late at ten, in spite of the lond murmurs of Erasmus, who sat half-starred at his work. When at length they sat down, a party of eight or nine, the pièce de resistance was, once at least, a bowl of vinegar, with seven small lettuce leaves floating in it, winding op with a stony cheese. Yet the meal often lasted more than an hour, while they amused themselves with telling stories, and soaking their chalky bread-a necessary operation, for it was only baked twice a month-in a dreggy wine, largely dilated with water. When Andrea was in a generous mood, he would bring homo three banches of grapes as a special dainty; or, if grapes weru out of season, a farthing's worth of shellfish; and then 'you would have thought there was to be a wedding in the family, for there had to be a fire, though they were very quickly cooked.' At other times the chief dish was a soup, made of akimmed-milk chees, followed by stale tripe; and on fish days they had three small whiting for eight people. All these dishes were rapidly taken away, as the ladies made their meal upon the remains. At longth Erasmus begged for the fourth part of a boiled fowl at each meal ; even this came np 'as dry as a chip, for the women lapped op all the gravy ;' but his host only allowed two starred 
pullets a week, and on the odd meat-day he would pretend that he forgot to go to market. On fast-days a friend was privately employed to smuggle in three nerr-laid eggs; but these were whisked off by the servants, who put rotten ones in their place. The unkindest cut of all was when Aldus took Erasmus gently to task for his large eating, warning him of the dangers of indulging a northern appetite in a southern clime; and at last, having one day found him furtively munching some confectionery, he privately begged a physician who was the friend of both to remonstrate with him on the subject. The doctor, however, had no better success; for his prescription was that he should leave off suppers altogether, and mix half water with his wine. Erasmus tells us, in one of his later works, that he soon came to the best solution of the difficulty, viz. to keep his own table in a private room. He allows, however, at the end of this lively collogay, that his hosts throve on their slender fare, and concludes that the quantity of food and drink is more a matter of custom tinan of nature.

It has been said by some that the freedom of this satire, disguised though it was, cansed an estrangement between Erasmus and the family of Aldus. ${ }^{10}$ Yet it was probably not written till 1591-after the deaths both of Aldus and his father-in-law-and we find Erasmas in friendly correspondence with the son of Andrea " more than twenty years after his visit. In his defence it must be said that, just before its publication, he was brutally attacked by J. C. Scaliger-the fiercest literary gladiator of his time-in his first pamphlet against the 'Ciceronianus;' and that the latter professed to heve private information from Venice as to the conduct of Erasmus during his stay. He represents that he acted as a kind of hired parasite to Aldus, and that his hosts were disgasted with the sloth and inebriety of one who 'drank like a three-mouthed Geryon.' Much of this cosree slander refates itself, and only recoils upon his accuser; bat it is doubtless based upon the fact that Erasmus did not conform to Italian ideas of temperance.

We know from scattered notices in his works that he was not debarred on this account from the most brilliant society in Venice. He was invited to supper with the victorious general D'Alviano, but was compelled to decline. He was introduced to Bernardo Ruccellai, a relative of the Medici, and a rriter of elegant contemporary histories in Latin, 12 bat could not induce him to use

10 The sappresoion of the name of Eramus in some later Aldine editione, and the substitution of 'Batarus quidem homo,' Wes doe, not to this cause, as is sometimes stated, but to a fenr of his enemies, the monka.

11 H. de Nolbac prints fom hithorto mpublished letters to Francesco d'Asale

12 Eresmag himself compares his rorts to Bellust. 
that language in conversation. 'You speak to deaf ears, most noble sir,' said Erasmus. 'I am as ignorant of your volgar tongue as I am of Hindoo.' He often dined with the learned Greek, John Lascaris, once an intimate friend of Lorenzo, who now occupied the high post of French ambassador to the republic. Perhaps it was at the suggestion of Lascaris that he ras admitted a member of the New Academy, which was founderl by Aldus about 1500 for the promotion of Greek studies. This learned body met once a week in the evenings to collate manuscripts, choose works for the press, and discuss general questions of scholarship. The members bound themselves alwars to speak in Greek on penalty of a small fine; the fines were sared ap, and spent in an occasional banquet. Here he met Dacas, Joln of Crete, and other Greeks, whom Aldus had gathered round bim as copyists and correctors; here he met also several learned Italians, who became lis fast friends. He speaks of one of the founders, Paolo Canale, who died of consumption during his stay, as 'a young noble of the utmost promise, born for great things if death had not envied men his talents.' A more mature scholar, Fra Urbano Bolzani, who had been Greek tutor to the sons of Lorenzo, and had travelled on foot tbrough many Eastern countries, assisted him in the preparation of his 'Adagia' So, too, did Battista Egnazio-once a pupil of Politian-' a sound and true friend,' as Erasmas calls him, who was afterwards sent to Paris to represent the repablic on the accession of Francis I. With the lastnamed, and with the doctor Leoni, the wittiest member of the circle, Erasmus maintained a correspondence to the end of his life. How affectionately he was himself remembered may be judged from the hearty reception given by his friends at Venice, nine years later, to Ulrich von Hutten, when he presented letters of introduction from Erasmus. Another friend, of whom he saw much during the first months of his stay, was Jerome Aleander, afterwards famous as papal nuncio at Worms. Aleander, who was not yet thirty, had a great reputation as a scholar, and gave Aldus valusble help in several of his publications. He was at this time living in the house, and, according to one account, shared a room with Erasmus. Soon after Easter he was summoned by the French king to occupy the Greek chair at Paris, and his subsequent rise was rapid. Erasmus greatly admired his abilities, which be thought were thrown away on politics; but he had no respect for the man. Hard words often passed between them in the first storm of the Reformation; bat they met more than once on guarded terms of friendship; and they must have looked back with pleasure to those quiet weels at Venice, when Aleander supplied materials for the 'Adsgia,' and Erasmus gratefully gave him letters of introduction to his friends at Paris.

At length, in September 1508, the 'Adagia' were issued in folio. 
They are a notable monoment of the lesming of the age, and immensely incressed the author's fame, though they were not yet adorned with his bold digressions on abuses in church and state. They wero received with enthusiasm all over the continent, and were reprinted eleven times in the next twelve years by one publisher at Strassburg. In the preface, addressed to his friend Mountjoy, Erasmus expresses his marmest thanks to Aldus for his generous belp. The latter would gladly have kept him longer at Venice, and even proposed receiving lessons trom him in rhetoric. He did employ him for some days in deciphering some manuscripts of Plautus and Terence, for which he gave him twenty crowns. But an engagement, probably procured for Erasmus by his friends in England, called him away to Padus about the beginning of October. Alerander, a natural son of James IV of Scotland, and already, at eighteen, archbishop of St. Andrews, was studying law at the nniversity; and Erasmus had agreed, at the hing's request, to instruct him in rhetoric. His new pupil was gentle and amiable, and soon won the affection of his teacher. At Padua Erasmus was still in the territory of the republic, and in constant communication with his old friends. And here, as was his wont in all his travels, be soon mode new triends, among whom were Texeirn, afterwards totor to the able Portuguese king, John III, and Germain Brice, with each of whom he afterwards corresponded. He found at Padua, as professor of Greek, Marcus Musurus, another light of the Aldine academy, with whom he had been intimate at Venice. This Cretan scholar had been brought over to teach Greek in Italy by John Lascaris, who had himself given him Latin lessons. He was now in the prime of life, and in himself a perfect encyclopedis of classical hnowledge. His lectures were attended by crowds of students-' like chickens under 8 hen,' as Leoni described them in after days. We get a bright glimpse of the rensissance enthusiasm for learning when we hear from Erasmus that Raphael Reggio, the professor of Latin, who was over seventy years of age, used to attend these lectures regalarly at seven in the morning, in all the rigours of an exceptionally cold winter. Erasmus had the highest esteem for the character of Musurus; he calls his teaching 'the richest and best mart of study in the world ;' and in later days he sent him more than one promising scholar. We can fancy the assistance he would himself derive from such a teacher in the work on which he was now engaged, of collating some Greek manuscripts which he had borrowed from Aldus. He tried to borrow otherg from the monks of Padus, and was told that when money and entreaties were useless, the only resource was theft.

Erasmus was not unaware that many Italian scholars of the time, in their enthusiasm for antiquity, almost lost sight of the Christian faith. - Bat he expressly says that at Padas thero was a 
higher religions tone than elsewhere. The witness is surprising; ${ }^{\text {is }}$ for one of the professors at this very time was the well-known Pomponazzo, who, in a work published in 1516, denied the immortality of the soul. It is true that, when threatened with the censure of the charch, he explained that he only denied it on groands of natural reason, and accepted it as a Christian. 14 Yet there is no doubt about the infidel tendency of his teaching; though his influence may bave been partly counteracted by Tomeo, another professor, deeply read in Plato, who was a man of the highest character. Erasmus must have often the diminative figure of Pomponazzo in the streets of Padua ; and the high opinion which the professor entertained of his own talents wonld make it difficult for him to be hid.

We have two short letters of Erasmus to Aldus, written at the close of his stay at Padua. From these we learn that he left the city, with his pupil, about the middle of December, alarmed, like the other students, by the ramours of impending war. On 10 Dec. 1508 was formed the celebrated league of Cambray, in which France, Spain, the emperor, the pope, and most of the minor states of Italy allied themselves against the repablic of Venice. No wonder that 80 formidable a combination spread terror in her dominions. Erasmus, 'detained,' he says, 'by the spells of Germain Brice,' stayed as long as he conld; bat the second letter announces his immediate departure. 'Accursed wars!' he writes, 'they prevent my enjoying a part of. Italy which delights me more every day. Farewell, my best of friends! I will give Bombasio your message and kind regards in person.'

Their first resting-place was Ferrara, where they remained a day or two. Different, indeed, is the Ferrara of to-day from the prosperous city visited by Erasmus. Now, ins then, the dark-red square tower of the castle of Este, gloomy and massive, frowns down upon the approaching traveller. Bat now the streets are grass-grown and almost deserted; and the windows of many of the houses are boarded up, as if in despair of the advent of a tenant. Then, though the city had been largely extended by its sagacious princes, no houses were to be let; and a thriving population of 100,000nearly four times its present number-cheerfully supported an immense weight of taxation. The reigning duke Alfonso, and his wife, the amiable and accomplished Lucrezis Borgia, were ardent patrons of learning; and the aniversity was one of the most famous in Furope. Ferrara, like so many Italian towns, could boast of a knot of scholars whose researches shed lustre upon her name.

11 The pacrege is in a letter to Hermenn Friside. Tet Hallem, following

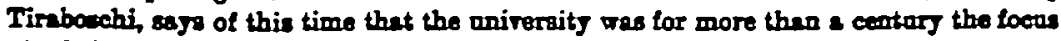
of atheiem in Italy (Lit. of Exroper, i. 321).

" Boocalini (Ragguagli da Parraso, Cent. i Reg. 80) makes Apollo decide after this defence that Pomponerso should be excalpated as a man, and burnt only as a philosopher. 
Erasmus and his party were received into the house of his old friend Richard Pace, afterwards English ambassador at Rome; and the literary chiefs of the town assembled there to do honour to the author of the 'Adagia.' Among them were Leoniceno, the physician and first translator of Galen, still hale though over eighty, and desiined to live to be ninety-six; Richeri (he preferred to call himself Rhodiginus), who was compiling a work on antiquities-the marvel of after times; and Calcagnini, the professor of belleslettres, a young poet and orator of no mean order. The last-named made an harangue of welcome to Erasmus in such elegant Latin that the latter says his tongue failed him in reply. They then sat domn and discussed some of the 'Adagia,' Erasmus pulling a copy out of his trunk in order to explain them with more effect. ${ }^{13}$ Such a circle of admirers might well have tempted him to prolong his stay ; but Ferrara was too near the expected theatre of war, and Erasmus pushed on to Siena, which he reached about New Year's Day, 1509.

This city was now governed by the despot Pandolfo Petrucci, whose wary diplomacy had kept him free from the political embroilments of the moment; and it proved a haven of rest to Erasmus. The bracing air of its hills seems to have improved bis health, which had suffered much during the past two years. He gives us a pleasing picture of the course of study which he now pursued with his pupil. He used to give him some subject for rhetorical composition, on which they talked together the next day; and every morning Alexander translated a passage from some Greek anthor. The afternoons were given by the prince to singing, learning the flute, and other music, of which he was passionately fond ; and in his leisure hours he read Roman history. During meals passages of the fathers were read aloud by a priest. Erasmas spent some of his time in writing short moral themes for his pupil, one of which, a declamation on desth, still survires. Nor were amusements despised. They threaded the crooked streets on 21 Feb. to the carnival fetes in the Piazza del Campo; and there mitnessed a strange entertainment, ${ }^{16}$ in which a ball was placed in the arena to face a huge wooden tortoise, whose creaks and contortions, produced by ropes and pulleys, terrified it into flight. But Erasmus was now impatient to Bome, which was within three or four days' journey ; so he left his pupil to prosecute his studies at the university of Siens, and entered the Eternsl City about the beginning of Lent.

Those who search the works of so ardent a lover of antiquity for any particular notices of the monaments of ancient Rome will

is These reminiscances are taten trom a correspondozce bstween Caleagrini and Enemus in 1025.

10 Described in Eramos's Supputatio errorum Bodac. 
find nothing to rerrard them. Perhaps Erasmus himself was disappointed that so little remained to be sten; at least he writes in later years, 'Old Rome does not exist, except in ruins and rubble, the traces and scars of her old disasters; take away the pope and cardinals, and what would Rome be?' Tet in the time of Erasmus far more of old Rome remained than is the case to-day. The Baths of Constantine were in existence; the Coliseum was more perfect; the Arentine, the Cælian, and the Esquiline were covered with ruined palaces. It seems clear that Erasmus's love of antiquity was exclusirely literary; he had no sentimental feeling about ruins, and could not sympathise with the archæological enthusiasm that bad lately arisen in Roman circles. It was an age with a passion for antiques; gems, crmeos, and coins had acquired a ralue hitherto anknown. Only a fer months before the grand sculptured group of the Lrocoon had been found in the Baths of Titus, and had made the fortune of the luclyy discoverer; while the poetasters vied with each other in producing rerses on the erent. Erasmas was certainly introdaced to Angelo Colocci, the virtuoso of the day, whose vills and gardens were richly adorned with the remains of ancient art. To the lovers of modern art what more glorious era conld there be for a visit to Rome than the later years of the pontificste of Julius? Bramante was just beginning his colossal plan for the rebailding of St. Peter's; Michael Angelo had been summoned to decorate the Sistine chapel ; and Raphasel was already painting in the chambers of the Vatican. Erasmas had a strong taste for art, as is proved by his remarks on Holbein and Albert Dürer; he once speaks of sculpture and painting as 'a silent poetry.' He most probably visited Raphael's stadio, though we need not believe the story that he showed him some of the works of Holbein.

The short weeks which he spent at Rome in the spring of 1509 were given almost entirely to the observation of manners and the pleasures of friendship. He was fortanate enough to find in Rome a friend whom he had known at Bologna, Scipio Carteromachns, an eminent scholar and one of the earliest members of the Aldine academy. Scipio left Rome about ten days after Erasmus arrived, but he devoted that time to him almost entirely, living in the same house, and introducing him into the best literary circles. In this way he may have met Sadolet, as he certainly met Egidius of Viterbo, one of the ablest as well as one of the most saintly men of the time. He tells us that he sometimes shared a bed with Ginlio Camillo, an eccentric genins of the day, who spent forty jears in constructing a strange machine, called a theatre, for tabulating all the operations of the mind under the signs of astrology. The academy of Leti mas still in existence; and at its meetings Erasmus met old Marso, one of its earliest members, and two former Bologna friends, Berosido and 
Spherula He also attended the receptions of a countryman of his own, John Goritz, who held an office at the papal court, and kept almost an open house for men of learning at his palace on the Quirinal. Oar traveller was also introduced to Inghirami, librarian of the Vatican, called from his preaching sbilities the Cicero of the day. This accomplished prelate had acquired the nickname of Phedro from his excellent acting as Phaodra in Senecs's play of 'Hippolytus;' and he was particularly friendly to Erasmus, who always speaks of him by that name. Inghirami did the honours of the Vatican library for his new friend, and donbtless gare him access to some of the conventual libraries, far richer then than they were after the sack of Rome in 1527. Nothing made Erasmus look back more regretfally to Bome than the splendid libraries which he had visited; he longed to consult their wealth of manuscripts for his own works on the Bible and the Greek fathers.

Now, however, his chief aim was to see all that he could; and his writings show the keenness of his observation-particularly the 'Praise of Folly,' which he wrote only a ferw weeks afterwards. He tells us that he was persuaded by his friends, much against bis will, to attend a bull-fight at the Vatican; and though be detested the cruelty of such a relic of old paganism, he describes, with evident relish, the drolleries of a masked baffoon, who, in the intervals, like the sham strong man at a circus, mimicked the actions of the real fighters. We can fancy him, too, taking the air in the Campagna, or watching the feats of the jugglers in the Campo de' Fiori, or reading with a contemptnous curl of the lip the rulgar lampoons that were affired every night to the base of Pasquino's statue. ${ }^{17}$ He notices the satirical rein of the populace, and ridicules the unhistorical pride which led them to suppose they were descended from the ancient Romans.

Meantime he heard from bis pupil that he had been ordered to return to Scotland, and that he wished, before doing so, to pay a visit to Rome ; Erssmus therefore returned to Biena, and brought him to Rome in the course of Holy Week. On Good Friday, 6 April, in the pope's chspel, they hesrd a sermon ${ }^{18}$ from one of the great preachars of the Curis before his holiness and the cardinals which strikingly illustrates the paganism of the period. The orator began with a eulogy of the pope, whom he compared to Jore poising in his right hand the deadly lightning, and regulating the world with his nod. In speaking of the Passion he recalled the derotion of Cecrops and Iphigenis, the Decii and Curtins in ancient bistory;

\footnotetext{
1 Pasquino was a Bomen trilor of cacetic wit, who lived shortly batore this time Soon after his death tho statuo of a gledietor wa dag ap and pleoed garer his abop, sed was popalarly ealled by his neme. Brasmas mose then once mentions tho 'paequinedes' on this atebre.

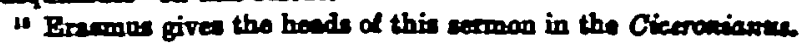


and compared the ingratitude of the Jews towards the Saviour to the treatment which Socrates and Aristotle, Epaminondas and Scipio, experienced at the hands of their countrymen. It is hard to say whether the pedantry or the irreligion of this discourse is the more remarkable; there was assuredly an abundance of both qualities at the papal court. It was not nncommon for literary men to speak of the mass as sacra deorum and of the cardinals as patres conscripti; and even ecclesiastics made it a fashion to treat religious subjects entiraly in the language of the classics. Erasmus speaks sadly of the unbelief which came under his orm notice; he one day spent some time in confating a philosopher, who relied on the authority of Pliny the Elder against the immortality of the soul. Bat he testifies to worse things than theseto a promiscuous hont after benefices, to men in society interlarding their conversation with blasphemy, and to priests of bad life parading their impiety at the mass. He was amazed at the tolerance shown to such persons by the anthorities; like Luther, who was at Rome for a fortnight in the following year, he must have sometimes thought- ' the nearer to Rome the further from Christianity.' It is plain, too, from the 'Praise of Folly,' that his Dutch simplicity was offended at the pomp and splendour of ecclesiastical life; he enumerates all the parasites of the Curia'that crowd of scribes, copyists, notaries, adrocates, secretaries, valets, grooms, bankers, agents, so onerous-(what did I say?) honourable to the Boman see.' Nor condd he have been blind to the darker side of the picture - the heavy debts incurred by many of the cardinals to keep up their position, and the scandalous mismanagement of the papal finances.

Yet he met with much personal kindness, as he often confesses, at the hands of the princes of the charch. He was on terms of intimacy with the cardinals of Nantes and of Bologna, and was sometimes invited to the table of the more famous cardinal de' Medici, who afterwards, as Leo X, wrote to him that he had pleasant recollections of their friendly talks together. His chief patron, however, was Rapbael Riario, cardinal of St. George, greatnephew of Sirtas IV, who was already one of the senior members of the college, though he lived to conspire against Leo, as he had joined in a conspiracy against his father Lorenso. This wealthy prelate resided in a noble palace built for him by Bramante, not the papal chancery, the erection of which necessitated-a strange vandalisen for those days-the destruction of the Arch of Gordian. The cardinal desired Erasmus to write a memorandum on the war with Venice, which was then being discussed in the consistory. Erasmas, who had so many friends at Venice, wrote a strong diatribe against the war, which he called 'Antipolemus; but his patron, who knew that this would be useless, seems to have persuaded 
him to soften it down into expressions of regret at the necessity. There is an unlikely story that Julius, displeased at its moderation, sent for Erasmus, and ordered him not to meddle in the affairs of princes. Unfortunately the pamphlet has perished; and so we cannot tell how far Erasmus sacrificed his principles at the shrine of friendship. The cardinal remained much attached to him, and afterwards wrote, promising, if he would retarn to Rome, to procure him a position worthy of his merit.

Before leaving Italy, the young prince Alexander, with Erasmus, made a hasty trip to Naples - a hind of pilgrimage to the tomb of Virgil and the cave of the Sibyl. ${ }^{19}$ There is bat one allusion to this journey in the works of Erasmus, and that is to the well-known grotto of Pausilippo-a tunnel of unknown age, about a mile long and some fifty feet high, under the hill to the north of Nuples. 'As you go,' he says, 'from Naples to Cumæ by the subterranean passage under the mountain, you can see, through the thick gloom, a little speck of light like a star, which seems to promise an exit.' On the hill above the grotto is the so-called tomb of Virgil, at which our travellers paid their tribute of veneration, and then returned to Rome by the Appian Way. Here the prince bede adieu to his tutor, to whom he gave, as a mark of his regard, an antique ring with an inscribed stone. One can imagine with what grief Erasmus wonld hear, four years later, of his death by his father's side on Flodden Field.

The third visit of Erasmus to Rome conld hardly have lasted more than a month-perhaps less; for in the early days of June he received two letters from England which were the canse of his leaving Italy almost immediately. One was from his friend Mountjoy, dated Greenwich, $27 \mathrm{May}$, announcing the accession of Henry VIII, and begging Erasmus to return at once; the other nas from the new king himself, adding his own entreaties to Mountjoy's and making liberal promises for the future. Mr. Froude has translated both these letters, and it is needless to recspitulate them. The first enclosed 10l. from Mountjoy and Warham for the expenses of his journey. We can hardly wonder that he instantly decided to accept so flattering an invitation. The king's letter seemed to promise not only pecuniary support, but a post of honour near his person; and Erasmus, though he was free from valgar ambition, Fas conscions of talent worthy of high station. It is clear, too, from his own admissions, that he did not like the religious atmosphere of Rome; the position in England promised more independence; and his weak health, which had suffered from the malaria of Italy, warned him to seek a more northern clime. His Roman friends, nevertheless, did their atmost to retain him; he ras told that he conld at once be made one of the pope's penitentiaries;

1s Probably the Iake of Arerno, near Kaples. 
and some hinted at the prospect of higher clignities. His orm resolution warered for a moment after paying a long-promised visit to the Cardinal Grimani of S. Mark, in his palace nor called the Palazzo di Tenezia. He has himself riridly described the interriew.

It was afternoon, and the porch and courtyard were empty. I left my horse with my servant and went in alone; in the first three rooms not a soul was to be seen, yet all the doors were open. - At last I found a little Greek doctor, as I supposed, who told me that the cardinal was conversing with sereral nobles. As I was looking out of the window, the Greek came up and asked my name. Then I had given it, he disappeared ; but returned at once, and ushered $m e$ in. The cardinal received me, not as such a prelate might be expected to receive so insignificant a persounage, but like one of his own colleagnes. Thes placed a chair, and we talkerl for more than tmo hours without his allowing me to uncover. He begged me not to leare Rome-the nurse of high talent-and invited mc to become his gnest and ghare his life: he added that his part of the town would especially suit my health. After much talk he sent for his nephew - a clever young man, already an archbishop; and when be came in, would not suffer me to rise, declaring that the scholar should stand in the presence of the master. He then shorred me over his magnificent library, which costained books in many languages. If I had known that man earlier I should never have left a city where I had met with a welcome so much above my deserts. But my departure was so far fixed that I could not honourably remain at Rome. The cardinal made me promise to see him again before I left.

He did not, however, keep this promise.

'I have fled without seeing you,' he wrote to the cardinal; ' my tottering resolution would have yielded; your eloquence and lindness would have made me stay. I already felt a strong love of Rome; and if I had not riolently torn myself away I should not have been able to leare it.'

He promised himself, however, a speedy return; and in latcr years he every winter formed some plan for another visit, till at length his health and, perhaps, the course of political events rendered it impossible:

In the middle of June he left Rome, as it proved, for the last time; and giring only one night to Bombasio at Bologna, with whom he left a kind message to Aldus, he crossed the Alps by the Splügen to Constance, and passing through the forest of Breisgau to Strassbarg, he embarked on the Rhine, which carried him swiftly to Holland. During the journey he rliled away his time, on horseback and by hoat, in composing his powerful satire, the 'Praise of Folly,' writing down his thoughts each evening at the imn. In one of the liveliest of his Collonplues, cillecl 'Diversorin,' ${ }^{\circ}$ he has described for us his meomfortalble experiences at these Germiun

- Mrr. Seebolim and other biograplicrs place the lively experienecs of the Dirersoria on the road to Italy; sct Erasmus did not then enter Germany. The routo in tho text is given by Rlenanus. 
inns; and the magic touch of Scott has popdarised the description in one of the most charming chspters of Anne of Geierstain. By the middle of July Erasmus Fas once more in England, in the hospitsble home of his friend More.

Mr. Seebohm, in his 'Oxford Reformers,' has spoken of this sojourn in Italy as if it brought to Erasmus nothing but disappointments and discomforts. There are certainly erpressions in his letters which accord with this vier; he seys, for instance, in a moment of ill-humour, that he learnt very little in Italy. But in his better moods he paid a juster tribute to the variety of his new experiences and to the kindness of his many learned friends. He says, elsewhere : 'I left Italy with regret and in my own despite; no nation in the world pleases me so well as the Italians.' And in bis old age he rrites : 'My heart is in Rome, nor would I willingiy lay my bones elsewhere.' The last eighteen months, at any rate, of his stay bad been a time of happiness and of renown. Reviowing his career after the lapse of four centuries, we can see that the whole time was of the atmost value to him. His views of life had been enlarged by watching the manners and customs of the south; his scholarship had ripened by contact with the 'New Learning ' in its first home; and he had been fitly prepared to play his high part as on $\theta$ of the leaders of mankind along the path of progress and reform.

Edward H. R. Tathas. 